\title{
Evaluation of Antibacterial Activities and Cytotoxicity of Sclerocarya birrea Stem Bark
}

\author{
Abigail John Mai*, Michael Emmanuel, Patrick Ayim, Mohammed Bello Magaji \\ Gombe State University, Tudun-Wada, Gombe, Gombe State, Nigeria \\ Email: ^abinadmai@gmail.com, e.michael86@outlook.com
}

How to cite this paper: Mai, A.J., Emmanuel, M., Ayim, P. and Magaji, M.B. (2019) Evaluation of Antibacterial Activities and Cytotoxicity of Sclerocarya birrea Stem Bark. Open Access Library Journal, 6: e5706. https://doi.org/10.4236/oalib.1105706

Received: August 14, 2019

Accepted: September 15, 2019

Published: September 18, 2019

Copyright $\odot 2019$ by author(s) and Open Access Library Inc.

This work is licensed under the Creative Commons Attribution International License (CC BY 4.0).

http://creativecommons.org/licenses/by/4.0/ (c) (i) Open Access

\begin{abstract}
The research was aimed at the antibacterial studies and cytotoxicity of aqueous trona extract of Sclerocarya birrea (marula) stem bark. Extraction of the stem bark was carried out using decoction method from the dried stem bark of marula. The extract was subjected to phytochemical screening, antibacterial and cytotoxicity test. The extract indicated the presence of tannin, saponins and alkaloids with the absence of flavonoids, steroids and glycosides. An antimicrobial study of the extracts was carried out against Staphylococcus aureus, Escherichia coli and Klebsiella pneumoniae using agar-well diffusion method. The extracts with trona have higher zone of inhibition at $100 \mathrm{mg} / \mathrm{ml}$, Escherichia coli, (zone of inhibition =16), Staphylococcus aureus (zone of inhibition $=14$ ) and Klebsiella pneumoniae (zone of inhibition =9). The cytotoxicity tests were carried out on the extracts using brine shrimp lethality assay, the extract showed a mortality with 9 nauplii dead upon exposure at $1000 \mathrm{ppm}$, and had an $\mathrm{LC}_{50}$ value of $63.1 \mathrm{ppm}$. The FTIR characterization carried out on the extract indicates the presence of functional groups such as: $\mathrm{O}-\mathrm{H}, \mathrm{C}=\mathrm{O}, \mathrm{C}-\mathrm{N}$ and $\mathrm{C}-\mathrm{C}(\mathrm{O})-\mathrm{C}$ indicating peak of alcohols, carbonyl group amine and ester.
\end{abstract}

\section{Subject Areas}

Electrochemistry, Organic Chemistry

\section{Keywords}

Trona, Marula, Cytotoxicity, Antibacterial Activity

\section{Introduction}

In recent years, herbal medicine has gained numerous attention due to its relatively low side effect [1]. It was reported that about $80 \%$ of the world population 
especially in the developing countries, use herbs for the treatment of some disease [2]. Most pharmaceutical products depend on plants as the main source of material for their production [3]. Plant derived medicines can serve as a basis for the manufacture of different more active drugs [4] [5]. Most plants are made up of bioactive compounds such as lipids, phytochemicals, pharmaceutics, flavons, fragrances and pigments. According to World Health Organization, even developed countries are beginning to turn to plants for their medicine source due to the increased resistance of most existing antimicrobial drugs [6].

\section{Uses of Sclerocarya Birrea in Local Medicine}

Sclerocarya birrea has been reported to have antiparasitic effect and can be used in the treatment of trypanosomiasis also known as African sleeping sickness [7] [8]. The methanolic extract of its leaves was reported to cause a complete mortality of the trypanosoma brucei in vitro [9]. In vitro antiplasmodial activity and in vivo antimalerial activity of Sclerocarya birrea was carried out against $P$. falciparum and $P$. berghe respectively. Results reported showed that $P$. falciparum was more sensitive to the extract compared to $P$. berghe, with the methanolic extract found to be more active than the water extract [10]. In south and east Africa, the stem-bark of Sclerocarya birrea is used as a potent remedy for dysentery and proctitis [11]. The Zulus of South Africa use a decoction of Sclerocarya birrea stem bark as a propylatic remedy against gangrenous rectitis [12]. Decoctions or steam from boiled are prepared roots and used for the treatment of heavy menstrual flow in women, bilharzias, cough, weakness, sore eyes, and in heart pains. [13]. Traditionally the stem bark is used for the treatment of various gastrointestinal disorder especially dysentery/diarrhea, hemorrhoid, stomach ulcers and pain, sore throat/mouth and toothache [14]. Both the methanolic and aquous extract of this plant was found to be anti-inflammatory in rats paw induced edema, and with some antioxidant activity [15].

In this research we evaluate the antimicrobial activity and cytotoxicity of the stem bark of Sclerocarya birrea trona extract

\section{Materials and Method}

Fresh stem bark of Marula (Schelerocarya birrea) was aseptically collected from Doho Ward Kwami Local Government of Gombe State, Nigeria using a cleaned cutlass, and was transported in cleaned polythene bag and sacks to the lab in the Chemistry Department of Gombe State University. A soft brush was used to remove any dirt/debris from the plant materials. The fresh stem bark of marula was air-dried under a shade for two weeks for proper drying and stored in an air tide container for used. The plant was identified at the Gombe state university herbarium of the department of biological science with a voucher number 460 .

\subsection{Water-Trona Extraction (Decoction Method)}

$500 \mathrm{~g}$ of dried sample of marula stem bark and $2 \mathrm{~g}$ of trona were extracted by 
boiling in $2000 \mathrm{ml}$ of distilled water for 60 minutes. The extracts were then filtered using Whatman Filter Paper No. 1, and the filtrate were concentrated using rotary evaporator, the crude extracts obtained were dried on a water bath and stored in an air tight container.

\subsection{Phytochemical Screening}

The phytochemical composition of the extracts of the plant materials were analyzed for the presence of saponins, steroids, tannins, flavonoids, alkaloids and glycosides according to standard methods [16].

\subsection{Antibacterial Activity}

The antibacterial activity of the crude extract was determined in accordance with Agar-well diffusion method [17]. The test organisms (Echerichia coli, Klepsiella pneumoniae and Staphylococcus aureus) were collected from Microbiology Department, Gombe State University and were authenticated by biochemical tests. The test organisms were aseptically sub cultured on nutrient agar for twenty four hours inside of incubator at $37^{\circ} \mathrm{C}$. Using inoculation platinum wire loop, enough material from an overnight culture of the test organism was transferred into a test tube containing normal saline until the turbidity of the suspension matched the turbidity of the $0.5 \mathrm{McFarland}$ Standard [18]. Sensitivity test was conducted following the agar-well diffusion method [17].

\subsection{Cytotoxicity Test}

Brine Shrimp Lethality Test

Artemia salina nauplii ( $<48 \mathrm{hrs}$ old) was exposed to a sample solution for $24 \mathrm{hrs}$ and frequencies of immobility of the 10 nauplii in $5 \mathrm{ml}$ solution were scored.

\subsection{FTIR Analysis}

The FTIR analysis of the two extracts was carried out in Gombe University, Faculty of Pharmaceutical Sciences. The FTIR spectra of the extracts which extracted with trona and the extract without trona were recorded in the range 4000 - $450 \mathrm{~cm}^{-1}$ using Perkin Elman Spectrum version 10.03.06.

\section{Results and Discussion}

\subsection{Phytochemicals Screening}

The result shown on Table 1 indicated that marula stem bark extract contains tannins, alkaloids, and saponins while flavonoids, steroids, and glycosides are absent. The results of the current research are in agreement with the one reported by Kutama et al., (2013) [19], with an observed difference which might be due to the difference in method of extraction, trona, high temperature and sample sizes.

\subsection{Antimicrobial Activity}

The result of antibacterial study of the stem bark of Sclerocarya birrea (marula) 
and the standard antibiotic used are presented in the Table 2. The aqueous extract with trona was found to be effective in inhibiting the growth of the three tested bacteria as demonstrated by an agar well diffusion method. The aqueous extract shows higher zone of inhibition at a concentration of $100 \mathrm{mg} / \mathrm{ml}$, and the zone of inhibition increases with the increase in concentration of the extract.

\subsection{Cytotoxicity Test}

The result obtained from cytotoxicity of the marula stem bark extracts using brine shrimp lethality assay as shown in Table 3 shows that the effects of the

Table 1. Results of phytochemicals screening of marula stem bark with trona.

\begin{tabular}{cc}
\hline Phytochemicals & Aqueous Extract \\
\hline Flavonoids & + \\
Saponins & - \\
Steroids & + \\
Alkaloids & - \\
Glycosides & + \\
Tannins & + \\
\hline
\end{tabular}

Key: + = Present; - = Absent.

Table 2. Results of antimicrobials activity of marula stem bark extract with trona.

\begin{tabular}{cccc}
\hline Test Organisms & $\begin{array}{c}\text { Concentrations } \\
(\mathrm{mg} / \mathrm{ml})\end{array}$ & $\begin{array}{c}\text { Zone of Inhibition } \\
\text { Diameter }(\mathrm{mm})\end{array}$ & Ciprofloxin \\
\hline Escherichia coli & 100 & 16 & 24 \\
50 & 9 & \\
Staphylococcus aureus & 12.5 & 7 & 23 \\
& 100 & NA & \\
Klebsiella pneumoniae & 50 & 14 & \\
& 25 & 10 & 23 \\
& 12.5 & 6 & \\
& 100 & NA & \\
& 50 & 9 & \\
& 25 & 6 & \\
& 12.5 & NA & \\
\hline
\end{tabular}

Key: NA = No activity.

Table 3. Result of Brine Shrimp lethality assay of extracts with trona.

\begin{tabular}{cccc}
\hline Concentration (ppm) & No. of dead nauplii & \% Mortality & LC50 Value (ppm) \\
\hline 1000 & 9 & $90 \%$ & 63.1 \\
100 & 6 & $60 \%$ & \\
10 & 3 & $30 \%$ & \\
\hline
\end{tabular}


crude extract of Sclerocarya birrea on the mortality rate of the brine shrimp (Artemia salina) depend on the types of crude extracts and its concentration. For aqueous extract with trona 9 nauplii died upon exposure at $1000 \mathrm{ppm}$ whereas at $100 \mathrm{ppm}$ and $10 \mathrm{ppm} 6$ and 3 nauplii died. This indicates that the number of mortalities increases with the increase in concentration of the extract and aqueous extract with trona has lethal concentration for $50 \%$ mortality $\left(\mathrm{LC}_{50}\right)$ value of 63.1 ppm. Values of the $\mathrm{LC}_{50}$ greater than $1000 \mathrm{ppm}$ indicates poor activity, and values lower than $1000 \mathrm{ppm}$ indicates higher activity of the plant extract [20].

\section{Conclusion}

An improved actibacterial activity was obtained from the trona extract of the neem stem bark. The extract was found to have potential for the treatment of diseases related to Staphylococcus aureus, Escherichia coli, Klebsiella pneumoniae with high efficiency. Since the activity of a plant extract is mostly related to the values of $\mathrm{LC}_{50}$ such that values below $1000 \mathrm{ppm}$ are found to be active and values above $1000 \mathrm{ppm}$ are found to be inactive, with the obtained value of $63.1 \mathrm{ppm}$, we can say that the plant extract is active and effective as an anti-bacteria for the treatment of diseases caused by Staphylococcus aureus, Escherichia coli and Klebsiella pneumoniae.

\section{Acknowledgements}

We wish to acknowledge the contributions of the botany department of Gombe state University, the microbiology department of Gombe State University, and the chemistry department of Gombe State University for providing us with the laboratory space for this experiment.

\section{Conflicts of Interest}

The authors declare no conflicts of interest regarding the publication of this paper.

\section{References}

[1] Iniaghe, D.M., Molomo, S.O. and Adebayo, J.O. (2009) Proximate Composition and Phytochemical Constituents of Leaves on Some Acalypha Species. Pakistan Journal of Nutrition, 8, 256-258. https://doi.org/10.3923/pjn.2009.256.258

[2] Cunningham, A.B. (1993) African Plants, Setting Priorities at the Inference between Conservation and Primary Health Care. UNESCO, Paris.

[3] Clark, A.M. (1996) Natural Product as a Resource for New Drugs. Pharmaceutical Research, 13, 1133-1141.

[4] McGraw, H. (1997) Encyclopedia of Science and Technology. McGraw Hill Publication, New York, 403-692.

[5] Iwu, M.M. (1993) Handbook of African Traditional Plants. CRC Press Book, Boca Raton, FL, 33-35.

[6] World Health Organization (2006) Traditional Medicine. Fact Sheet No. 134. 
[7] Grover, J.K. and Yadar, S.P. (2004) Pharmacological Actions and Potentials Uses of Momerdica charantia: A Review. Journal of Ethnopharmacology, 93, 123-132. https://doi.org/10.1016/j.jep.2004.03.035

[8] Fierman, J.K. (1981) Alternative Medicinal Services in Rural Tanzania: A Physician's View. Social Science \& Medicine. Part B: Medical Anthropology, 15, 399-3404. https://doi.org/10.1016/0160-7987(81)90067-3

[9] Mikail, H.G. (2009) In Vitro Tryponocidal Effects of Methanolic Extract of Sclerocarya birrea, Commiphora Kerstingii and Khaya senegalensis. African Journal of Biotechnology, 8, 2047-2049.

[10] Gathirwa, J.W., Rukunya, G.M., Njagi, E.W., Omar, S.A., Maritari, P.G., Guntai, A.N., Tolo, F.M., Kimani, C.W., Muthaura, C.N., Kirira, P.G., Ndunda, T.N., Amalemba, G., Mungai, G.M. and Ndiege, I.O. (2008) The in Vitro Anti-Plamodine and in Vivo Anti-Malaria Efficacy Combinations of Some Medicinal Plants Used Traditional for Treatment of Malaria by the Mens Community in Kenya. Journal of Ethnopharmacology, 115, 223-231. https://doi.org/10.1016/j.jep.2007.09.021

[11] Ecoff, J.N. (2001) Antibacterial Activity of Marula (Sclerocarya birrea (A. Rich) Hocst. Subsp. Caffra (Sond.) Kokwaro) (Anacardiaceae) Bark and Leaves. Journal of Ethnopharmacology, 76, 305-308. https://doi.org/10.1016/S0378-8741(01)00260-4

[12] Dimo, T., Rakotonirina, S.V., Tan, P.V., Azay, J., Dongo, E., Kamtchouing, P. and Cros, G. (2007) Effect of Sclerocarya birrea (Anacardraceae) Stem Berk Methylene Chloridel/Methanol Extract on Streptozotocin-Diabetic Rats. Journal of Ethnopharmacology, 1110, 434-438. https://doi.org/10.1016/j.jep.2006.10.020

[13] Shackleton, B.J. and Emmanuel, P.L. (2003) Productivity and Abundace of Sclerocarya birrea Subsp. Caffra in and Around Rural Settlements and Protected Areas of the Bushbuckridge Lowveld, South Africa. Forests Trees Livelihood, 13, 217-232. https://doi.org/10.1080/14728028.2003.9752459

[14] Wezel, A. (2002) Medical Plants and Their Traditional Use by Farmers in Niger. Etudes flor. veg. Burkina Faso., 6, 9-18.

[15] Ojewole, J.A. (2003) Evaluation of the Analgesic, Anti-Inflammatory and Anti-Diabetic Properties of Sclerocarya birrea (A. Rich.) Hochst. Stem-Bark Aqueous Extract in Mice and Rats. Phytotherapy Research, 18, 601-608. https://doi.org/10.1002/ptr.1503

[16] Trease, G.E. and Evans, W.C. (1989) Pharmacognicy. 11th Edition, Braillia Trindalt Can Ltd., MacMillan Publisher, London, 45-50.

[17] Irobi, O.N., Moo-Young, M., Anderson, W.A. and Daramola, S.O. (1994) Antimicrobial Activity of the Bark of Bridelia Ferruginea (Eupherbiaceae). International Journal of Pharmacognosy, 34, 87-90.

[18] CLSI (2012) CLSI Document M07-A9. Methods for Dilution Antimicrobial Susceptibility Test for Bacteria that Grow Aerobically: Approved Standard. 19th Edition, CLSI, Wayne.

[19] Kutama, A.S., Auyo, M.I., Umar, M.L. and Hadiza, M.S. (2013) Assessing the Antibacterial Activity of Marula (Sclerocarya birrea) Stem Berk and Leaf Extracts Against Some Selected Bacterial Isolates in Kano, Nigeria. World Journal of Agricultural Science, 1, 209-214.

[20] Meyer, B.N., Ferrigni, J.E., Jacobsen, L.B., Nichols, D.E. and McLaughlin, J.L. (1982) Brine Shrimp: A Convenient General Bioassay for Active Plant Constituents. Journal of Medical Plant Research, 45, 31-34. https://doi.org/10.1055/s-2007-971236 